\title{
How severe and prevalent are Ebola and Marburg viruses? A systematic review and meta-analysis of the case fatality rates and seroprevalence
}

Luke Nyakarahuka $^{1,2,5^{*}}$ (D), Clovice Kankya ${ }^{2}$, Randi Krontveit ${ }^{3}$, Benjamin Mayer ${ }^{4}$, Frank N. Mwiine ${ }^{2}$, Julius Lutwama ${ }^{5}$ and Eystein Skjerve ${ }^{1}$

\begin{abstract}
Background: Ebola and Marburg virus diseases are said to occur at a low prevalence, but are very severe diseases with high lethalities. The fatality rates reported in different outbreaks ranged from 24-100\%. In addition, sero-surveys conducted have shown different seropositivity for both Ebola and Marburg viruses. We aimed to use a meta-analysis approach to estimate the case fatality and seroprevalence rates of these filoviruses, providing vital information for epidemic response and preparedness in countries affected by these diseases.

Methods: Published literature was retrieved through a search of databases. Articles were included if they reported number of deaths, cases, and seropositivity. We further cross-referenced with ministries of health, WHO and CDC databases. The effect size was proportion represented by case fatality rate (CFR) and seroprevalence. Analysis was done using the metaprop command in STATA.

Results: The weighted average CFR of Ebola virus disease was estimated to be $65.0 \%$ [95\% Cl (54.0-76.0\%), $\left.I^{2}=97.98 \%\right]$ whereas that of Marburg virus disease was $53.8 \%\left(26.5-80.0 \%, I^{2}=88.6 \%\right)$. The overall seroprevalence of Ebola virus was $8.0 \%\left(5.0 \%-11.0 \%, I^{2}=98.7 \%\right)$, whereas that for Marburg virus was $1.2 \%\left(0.5-2.0 \%, I^{2}=94.8 \%\right)$. The most severe species of ebolavirus was Zaire ebolavirus while Bundibugyo Ebolavirus was the least severe.

Conclusions: The pooled CFR and seroprevalence for Ebola and Marburg viruses were found to be lower than usually reported, with species differences despite high heterogeneity between studies. Countries with an improved health surveillance and epidemic response have lower CFR, thereby indicating need for improving early detection and epidemic response in filovirus outbreaks.
\end{abstract}

Keywords: Ebola virus disease, Marburg virus disease, Case fatality rate, Meta-analysis, Systematic review, Seroprevalence

\section{Background}

Ebola virus disease (EVD) and Marburg virus disease (MVD) are caused by filoviruses in the family Filoviridae and are both associated with high case fatality rates (CFR). The World Health organization (WHO) reports that the CFR of EVD ranges from 25.0 to $90.0 \%$ while that of MVD ranges from 24.0 to $88.0 \%$ [1]. In the early

\footnotetext{
*Correspondence: nyakarahuka@gmail.com; n3luke@covab.mak.ac.ug

${ }^{1}$ Norwegian University of Life Sciences, Oslo, Norway

${ }^{2}$ Makerere University, Kampala, Uganda

Full list of author information is available at the end of the article
}

phases of a major Ebola outbreak in West Africa, CFR was reported to be $70.8 \%$ [2]. The CFR of EVD seems to be species dependent with Ebola Zaire and Ebola Sudan species being most pathogenic (with a reported CFR of 100\%), while Ebola Bundibugyo appears to have a lower CFR at 34\% [3]. A recent study by Lefebvre et al. that used data from WHO database estimated the CFR of EVD to be $65.4 \%$ irrespective of the Ebola virus species [4]. A few studies have tried to pool the CFR of EVD and MVD, but did not use the meta-analysis approach [5]. 
Although EVD is known to be very severe, there are some species of Ebola virus that cause less serious disease. For example, Taï Forest ebolavirus, formerly known as Cote d'Ivoire ebolavirus, has not been associated with any fatality and the only case ever reported recovered from the disease [6]. While there have been some reports of EVD being associated with a CFR of $100 \%$, this CFR is attributed to only a single case fatality that did not result into transmission of the virus to other individuals $[7,8]$. It seems that CFR differs from species to species, however, both Ebola Sudan and Ebola Zaire have shown a CFR of $100 \%$ [1]. Also, the CFR of the MVD outbreak that occurred in Uganda in 2014 was reported to be $100 \%$, but again only one person was diagnosed and died from the disease [9]. The largest MVD outbreak was in Angola in 2004 with CFR of 90\% [10] and in Democratic Republic of Congo (DRC) in 1998 with CFR of $83 \%$ [11].

There is evidence that a substantial proportion of infected humans in Central Africa seem to recover without being detected by the health care system, and apparently healthy individuals have been found to be seropositive for Ebola and Marburg viruses [12-15]. Furthermore, Marburg virus has been found in apparently healthy cave-dwelling fruit bats of species rousettus aegyptiacus, which are believed to be reservoirs for Marburg virus, and responsible for the spill over into human populations [16-19]. Because of the variations in the reported CFR and the presence of seropositive individuals, it is important to determine the severity and prevalence of these viral haemorrhagic fevers. This is important for forecasts and risk analysis especially during outbreaks for epidemic preparedness and response by affected countries. This will help to estimate how many infected people with EVD or MVD are likely to die from the disease during outbreaks. Whereas there are few studies that have estimated CFR of EVD $[4,5]$, these did not use a meta-analysis approach and no meta-analysis has been performed on CFR of EVD, MVD, seroprevalence of Ebola and Marburg viruses. Therefore, our aim was to determine the overall weighted estimate (effect size) of the CFR and seroprevalence of EVD and MVD using available published literature on outbreak reports, WHO and CDC databases and population based studies for seroprevalence of filoviruses (Marburg and Ebola viruses). We also explored whether CFR and seroprevalence of these filoviruses differs according to virus species and country.

\section{Methods}

Procedures for systematic reviews and meta-analysis have been developed to summarize scientific evidence from the literature. This work was done following the guidelines published in the PRISMA statement [20] and MOOSE guidelines for observational studies [21] as follows.

\section{Literature search strategy}

A detailed literature search was conducted by the authors in PubMed (as well as Medline), Web of Science and Google Scholar until $5^{\text {th }}$ October 2015. In cases where there was no peer-reviewed publication for a known outbreak, data was retrieved from websites of WHO and CDC. The following key words were used; "ebola", "ebolavirus", "viral haemorrhagic fevers", "marburg virus disease", "marburg haemorrhagic fever", "marburg virus outbreak", "ebola virus disease outbreak", "marburg virus", "ebola outbreak", "seroprevalence of ebola virus", "seroprevalence of marburg virus" and "risk factors of viral haemorrhagic fevers". The search included all articles and outbreak reports about EVD and MVD and cross-referencing of primary articles was done to obtain the original articles. Since the number of outbreaks of EVD and MVD are known and few, efforts were made to obtain all information about these outbreaks from WHO and CDC websites and Ministries of health of respective countries.

\section{Study selection criteria}

Studies were included in the meta-analysis if they reported the total number of cases and total number of deaths from the outbreak of EVD or MVD. Also studies that were reporting CFR and sero-prevalence in percentages were included. Studies or reports that did not include total number of deaths or cases were excluded as well as studies that did not report original data (Fig. 1). We also excluded studies that reported outbreaks of Ebola species that are not pathogenic to humans and those species that have not caused mortality in humans. In cases where there were multiple publications, we used the one with the most complete data or the most recent one. In cases where there was controversy on the number of cases and deaths between studies, we crossreferenced with the respective ministries of health, WHO or CDC databases to reconcile these discrepancies. Seroprevalence studies included were only those that were population based and comprised apparently healthy individuals. We excluded articles that reported sero-prevalence during outbreaks or in sick individuals.

\section{Data extraction}

LN compiled a list of articles and discrepancies were discussed and resolved by consensus between FM, CK and JL. We used a standardized data extraction form and the following information was extracted for each qualifying study and outbreak report: i) author; ii) Country; iii) number of cases; iv) number of deaths; v) CFR (if reported); vi) month and year of outbreak; vii) year of publication viii) 


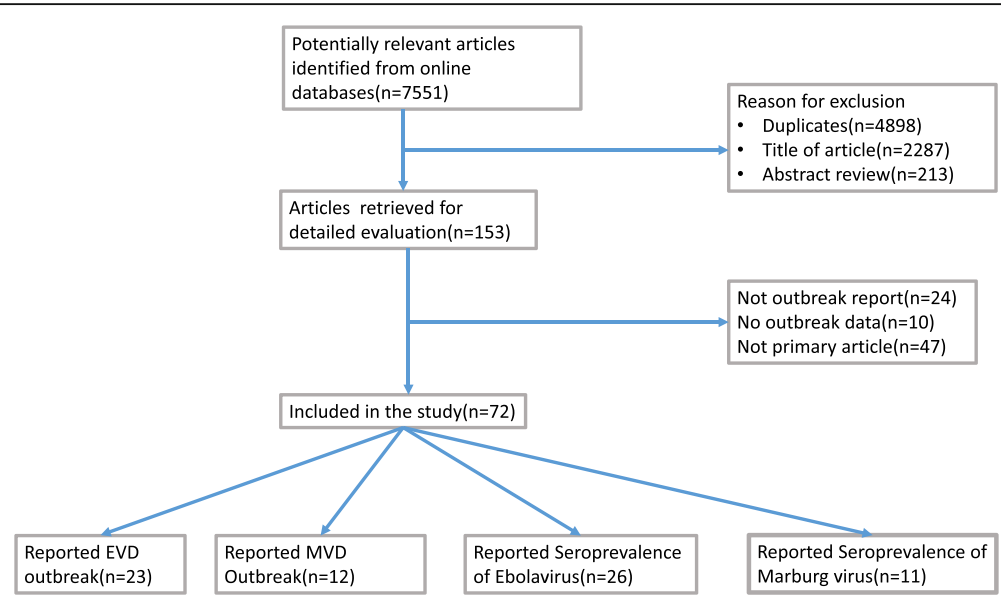

Fig. 1 Flow diagram for search strategy and article selection process from the literature databases

and species involved. For population-based seroprevalence studies, the following additional information was retrieved: i) sample size and ii) number of seropositive samples.

\section{Statistical analysis}

Data were collected in a Microsoft Excel $^{\circledR}$ spreadsheet and outcome measures were calculated. CFR was calculated as number of deaths divided by reported cases whereas seroprevalence was calculated as number of individuals seropositive divided by total sample size in each study. Our effect size (ES), the principal summary measure, was the proportion represented by CFR and seroprevalence. We used the newly developed metaprop command [22] for performing meta-analysis of binomial data in STATA (StataCorp, College Station, TX, USA). The metaprop command was preferred to metan command because it implements procedures that are specific to binomial data and is appropriate for dealing with proportions close to or at the margins and also uses the Freeman-Tukey double arcsine transformations to stabilize the variances [22]. The meta-analysis of CFR was stratified by country and species where possible.

The following parameters were estimated: Cochran's Q indicating differences in true ESs, an estimate of the true variance of ESs between studies (our estimate of $\mathrm{\tau}^{2}$ ) and Higgins $\mathrm{I}^{2}$ which is an estimate of what proportion of the observed variance that reflects real differences in ES. If $\mathrm{I}^{2}$ is close to 0 , then almost all the observed variation is spurious, and there is nothing to explain. If $\mathrm{I}^{2}$ is large, then reasons for the observed variance should be evaluated [23, 24]. Sensitivity analysis was done by excluding studies that reported very few numbers or zero deaths or no seropositives. A meta-regression procedure was done to assess if factors such as species, country, year and month of outbreak influence CFR of both EVD and MVD using the traditional logit-transformation: Logit (prevalence $)=\ln [$ prevalence $/(1-$ prevalence $)]$ Variance (logit) $=1 /(n p)+1 /[n(1-p)]$ [25]. The Begg's and Egger's tests were used in combination with a funnel plot to assess potential publication bias and visualised using funnel plots [24, 26].

\section{Results}

\section{Literature search result}

Results from the literature search are illustrated in Fig. 1. The literature search yielded 7551 articles. Of these, 4898 were excluded as duplicates. After reviewing the titles and the abstract, only 153 articles were retrieved for detailed evaluation. After full evaluation of retrieved publications, 72 articles were included in this study. Of those included in the study, 23 reported outbreaks of EVD (Table 1) [3, 8, 27-41, 7, 42, 43], 12 reported outbreaks of MVD (Table 2) [10, 11, 42, 44-51], 26 reported seroprevalence of Ebola virus (Table 3) [8, 12-14, 28, 31, $52-54,29,55-70]$ and 11 reported sero-prevalence of Marburg virus (Table 4) [14, 15, 57, 61-64, 67, 71-73]. Most of the sero-prevalence studies reported both Marburg and Ebola viruses.

Two more outbreaks have occurred without human mortalities namely Ebola Reston [74, 75] and another caused by Taï Forest virus [6]. Zaire ebolavirus species was responsible for most of the outbreaks with $14 / 23(60.9 \%)$ [8, 28, 30-32, 34-36, 39, 40, 41, 37, 76] followed by Sudan ebolavirus with $30.3 \%$ (7/23) outbreaks [27, 29, 38, 7, 42, 77] and lastly Bundibugyo ebolavirus $8.7 \%(2 / 23)$ [3, 42]. Most articles reported DRC $(7 / 23)[8,28,32,39,40,42,76]$ and Uganda $(5 / 23)[3,33,7,42]$ as countries most affected by EVD outbreaks. Other countries reported include Gabon (4/23) [31, 34, 36, 78], Republic of Congo (3/23) [35, 37, 41], South Sudan $(3 / 23)[27,29,38]$ and multiple countries in West Africa associated with the recent single outbreak [79-82]. Interestingly, most of the EVD outbreaks 
Table 1 Summary of the studies included in a systematic review and meta-analysis describing case fatality rate for Ebola virus disease in Africa

\begin{tabular}{|c|c|c|c|c|}
\hline Author and Year of Publication & Deaths & Cases & Country & Year and month of outbreak \\
\hline WHO International Study Team, 1978 [27] & 151 & 284 & South Sudan & 1976, June-November \\
\hline International Commission, 1978 [28] & 280 & 318 & DRC & 1976, Sept-Oct \\
\hline Heymann et al., 1980 [8] & 1 & 1 & DRC & 1977, June \\
\hline Baron et al., 1983 [29] & 22 & 34 & South Sudan & 1979, June-Oct \\
\hline Amblard et al., 1997 [30] & 30 & 49 & Gabon & 1994, November \\
\hline Khan et al., 1999 [32] & 255 & 315 & DRC & 1995, May \\
\hline Georges et al., 1999 [31] & 21 & 31 & Gabon & 1996, May \\
\hline Milleliri et al., 2004 [34] & 45 & 60 & Gabon & 1996, May \\
\hline Okware et al., 2002 [33] & 224 & 425 & Uganda & 2000, October \\
\hline Nkoghe et al., 2005 [36] & 97 & 124 & Gabon & 2000, December \\
\hline Rouquet et al. (2005) [37] & 128 & 143 & $\mathrm{ROC}$ & 2003, December \\
\hline Boumandouki et al., 2005 [35] & 29 & 35 & $\mathrm{ROC}$ & 2003, Oct-Dec \\
\hline Onyango et al., 2007 [38] & 7 & 17 & South Sudan & 2004, April-June \\
\hline Nkoghe et al., 2011 [41] & 10 & 12 & $\mathrm{ROC}$ & 2005, April-May \\
\hline Leroy et al., 2009 [39] & 186 & 264 & DRC & 2007, May and November \\
\hline Wamala et al., 2010 [3] & 39 & 116 & Uganda & 2007, August \\
\hline Grard et al., 2011 [40] & 15 & 32 & DRC & 2008, Jan \\
\hline Shoemaker et al., 2012 [7] & 1 & 1 & Uganda & 2011, May \\
\hline Albariño et al., 2013 [42] & 4 & 11 & Uganda & 2012, July \\
\hline Albariño et al., 2013 [42] & 3 & 6 & Uganda & 2012, Nov \\
\hline Albariño et al., 2013 [42] & 13 & 36 & DRC & 2012, August \\
\hline Maganga et al., 2014 [43] & 49 & 69 & DRC & 2014, July \\
\hline WHO, $2016[79,90]$ & 11323 & 28646 & West Africa & March, 2014 \\
\hline
\end{tabular}

DRC Democratic Republic of Congo, ROC Republic of Congo

Table 2 Summary of studies included in a systematic review and meta-analysis describing case fatality rate for Marburg virus from searched literature globally

\begin{tabular}{|c|c|c|c|c|}
\hline Author and Year of Publication & Deaths & Cases & Country & Year \& Month of outbreak \\
\hline Siegert, $1972[44,45]$ & 7 & 31 & Germany and Yugoslavia & 1967, August \\
\hline Gear et al., 1975 [91] & 1 & 3 & Johannesburg, South Africa & 1975, February \\
\hline Smith et al., 1982 [92] & 1 & 2 & Kenya & 1980, January \\
\hline Johnson et al., 1996 [49] & 1 & 1 & Kenya & 1987, August \\
\hline Nikiforov et al., 1994 [48] & 1 & 1 & Russia & 1990 \\
\hline Bausch et al., 2006 [11] & 128 & 154 & DRC & 1998, October \\
\hline Towner et al., 2006 [10] & 227 & 252 & Angola & 2004, October \\
\hline Adjemian et al., 2011 [51] & 1 & 4 & Uganda & 2007, June \\
\hline Centers for Disease \& Prevention, 2009 [50] & 0 & 1 & USA from Uganda & 2008, January \\
\hline Timen et al., 2009 [93] & 1 & 1 & Netherlands from Uganda & 2008, July \\
\hline Albarino et al., 2013 [42, 94] & 4 & 15 & Uganda & 2012, October \\
\hline WHO, 2015 [95] & 1 & 1 & Uganda & 2014, October \\
\hline
\end{tabular}


Table 3 Summary of studies included in a systematic review and meta-analysis describing sero-prevalence of Ebola virus from literature

\begin{tabular}{|c|c|c|c|}
\hline Author and Year of Publication & Sample size & Seropositive & Country \\
\hline Van der Groen and Pattyn 1979 [96] & 251 & 43 & DRC \\
\hline Saluzzo, Gonzalez et al. 1980 [97] & 499 & 17 & CAR \\
\hline Bouree \& Bergmann, 1983 [55] & 1517 & 147 & Cameroon \\
\hline Johnson et al., 1983 [56] & 741 & 8 & Kenya \\
\hline Van der Waals, Pomeroy et al. 1986 [57] & 225 & 30 & Liberia \\
\hline Meunier et al., 1987 [58] & 1528 & 319 & CAR \\
\hline Paix et al., 1988 [59] & 375 & 4 & Cameroon \\
\hline Tomori, Fabiyi et al. 1988 [60] & 1,677 & 30 & Nigeria \\
\hline Gonzalez et al., 1989 [72] & 5070 & 629 & Central Africa \\
\hline Mathiot, Fontenille et al. 1989 [61] & 381 & 17 & Madagascar \\
\hline Johnson, Gonzalez et al.1993a [63] & 427 & 75 & CAR \\
\hline Johnson, Gonzalez et al. 1993b [64] & 4295 & 914 & CAR \\
\hline Busico et al., 1999 [66] & 575 & 24 & DRC \\
\hline Nakounne, Selekon et al. 2000 [67] & 1762 & 104 & CAR \\
\hline Heffernan et al., 2005 [69] & 979 & 14 & Gabon \\
\hline Allela et al., 2005 [68] & 439 & 64 & Gabon \\
\hline Lahm, Kombila et al. 2007 [70] & 1147 & 14 & Gabon \\
\hline Becquart et al., 2010 [12] & 4349 & 665 & DRC \\
\hline Heymann et al., 1980 [8] & 1096 & 79 & DRC \\
\hline Burke et al., 1978 [28] & 984 & 38 & DRC \\
\hline Baron et al., 1983 [29] & 106 & 23 & Sudan \\
\hline Georges et al., 1999 [31] & 441 & 58 & Gabon \\
\hline Becker, Feldmann et al. 1992 [62] & 1288 & 11 & Germany \\
\hline Gonzalez, Nakoune et al. 2000 [14] & 1331 & 71 & CAR \\
\hline Bertherat, Renaut et al. 1999 [65] & 236 & 24 & Gabon \\
\hline Nkoghe, Padilla et al. 2011 [13] & 4349 & 667 & DRC \\
\hline
\end{tabular}

DRC Democratic Republic of Congo, ROC Republic of Congo, CAR Central African Republic

Table 4 Summary of studies included in a systematic review and meta-analysis describing sero-prevalence of Marburg disease from published literature

\begin{tabular}{llll}
\hline Author and Year of Publication & Sample size & Seropositive & Country \\
\hline Van der Waals, Pomeroy et al. 1986 [57] & 225 & 3 & Liberia \\
Gonzalez, Josse et al. 1989 [72] & 5070 & 20 & Central African countries \\
Johnson, Ocheng et al. 1983 [71] & 1899 & 8 & Kenya \\
Mathiot, Fontenille et al. 1989) [61] & 384 & 0 & Madagascar \\
Becker, Feldmann et al. 1992 [62] & 1288 & 34 & Germany \\
Johnson, Gonzalez et al. 199a [63] & 427 & 5 & CAR \\
Johnson, Gonzalez et al. 1993b [64] & 4295 & 137 & CAR \\
Gonzalez, Nakoune et al. 2000 [14] & 1340 & 33 & CAR \\
Nakounne, Selekon et al. 2000 [67] & 1762 & 35 & CAR \\
Bausch, Borchert et al. 2003 [15] & 912 & 15 & DRC \\
Borchert, Mulangu et al. 2006 [73] & 300 & 0 & DRC
\end{tabular}


occurred during months of May, June and July and no outbreaks were reported in the month of February.

\section{Meta-analysis and meta-regression of CFR and seroprevalence of EVD}

The weighted CFR of EVD from 23 outbreaks was 65\% (95\% CI: 54-76\%) (Fig. 2). There was a substantial between-study variance indicating heterogeneity in the overall CFR of EVD, $\mathrm{I}^{2}=97.98 \%$. On stratification by Ebola virus species, the CFR for Sudan ebolavirus was $53 \%$, Bundibugyo ebolavirus was $34 \%$, whereas that of Zaire ebolavirus was $75 \%$. From the meta-regression, the CFR for Zaire ebolavirus was higher compared to other Ebola species $(=0.006$, Coefficient $=0.19,95 \% \mathrm{CI}=0.063$ - 0.588). In sub-analysis analysis by country, the highest CFR for EVD was observed in Republic of Congo $(89.0 \%, 84.0-93.0 \%)$ whereas the lowest was found in Uganda (43.0\%, 27.0-61.0\%) (Fig. 3). However, the large West African EVD outbreak that affected multiple countries had an even lower CFR at 40\% (3940\%). The pooled ES for Ebola virus seroprevalence was $8 \%$ [5-11\%) with substantial between-study variance $\left(\mathrm{I}^{2}=98.7 \%\right)$ (Fig. 4$)$.

\section{Meta-analysis and meta-regression of CFR and seroprevalence of MVD}

The MVD CFR was lower than that of EVD (61\%) (Fig. 5). There was no significant difference between CFR of MVD and different variables in the metaregression model $(P=0.637)$. The pooled seroprevalence of Marburg virus was lower than that of Ebola virus at $1.2 \%(0.5-2 \%)$ (Fig. 6).

\section{Publication bias}

In the funnel plots, asymmetry was evident which gives rise to suspected publication bias (Fig. 7). Egger's test

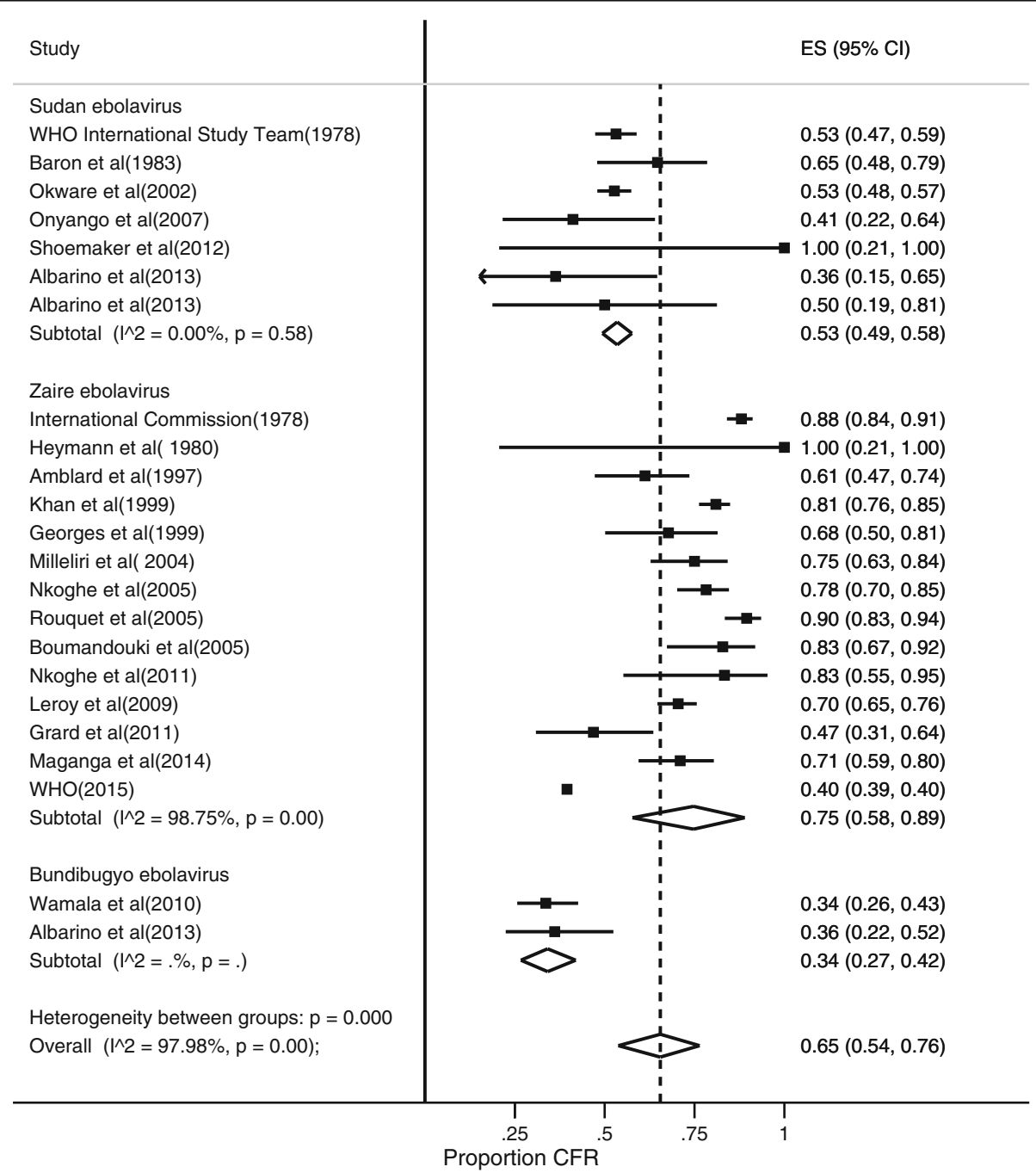

Fig. 2 Forest plot showing stratified meta-analysis of CFR of Ebola Virus Disease by virus species estimated by the random effects model $\left(I^{2}=\right.$ Higgins statistic, $\mathrm{ES}=$ Effect size, $\mathrm{Cl}=$ Confidence Interval $)$ 


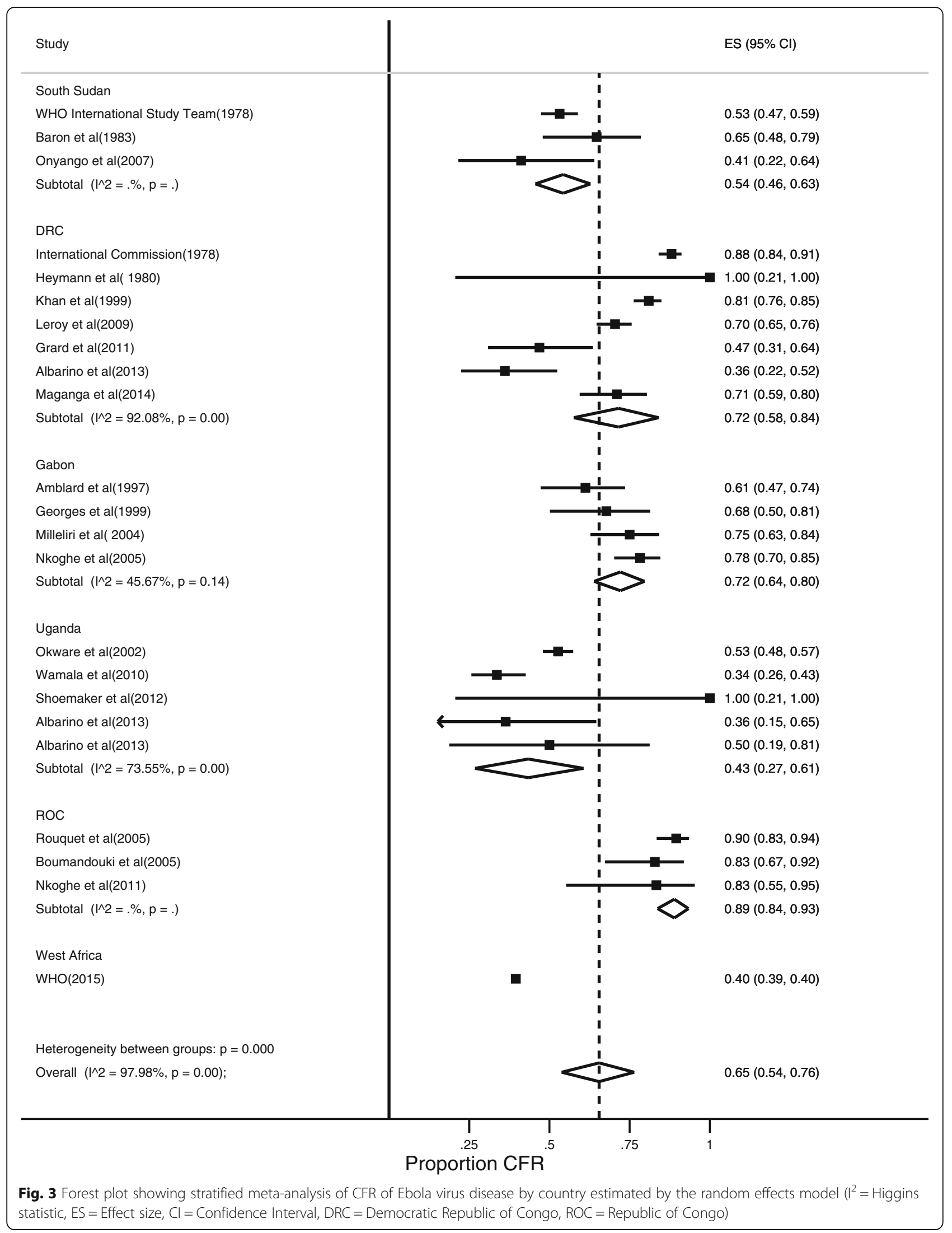




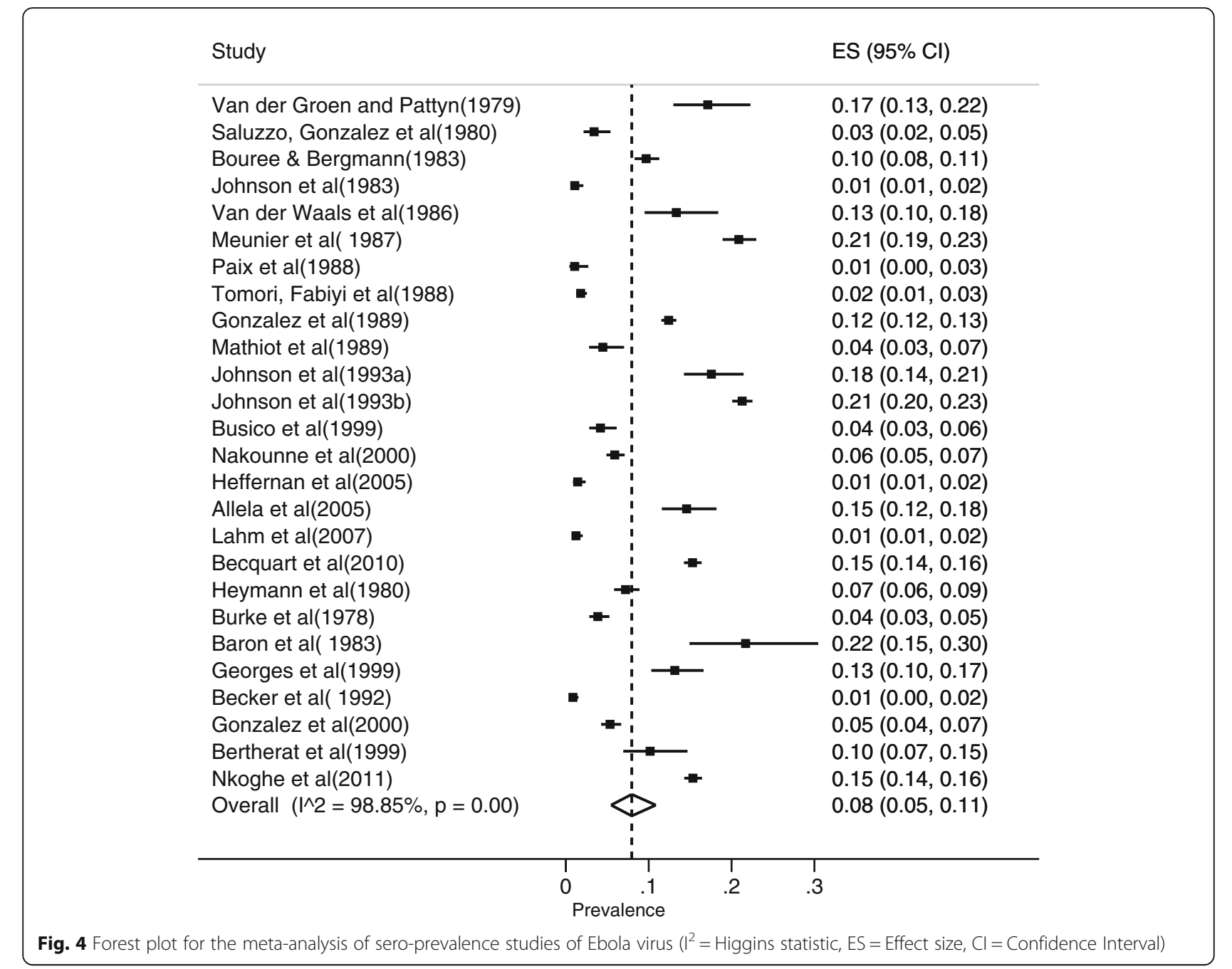

was significant for studies reporting CFR and seroprevalence of EVD and MVD $(P=0.001, P<0.001, p=0.032$, and 0.046 respectively). However, the Begg's bias test was not significant for studies reporting CFR of EVD and MVD ( $p=0.091$ and $p=0.293$ respectively), seroprevalence of MVD $(p=0.95)$, but was significant for studies reporting seroprevalence of EVD $(p=0.007)$.

\section{Discussion}

Our findings show that the overall pooled CFR of EVD of $65 \%$ was lower than the previously reported CFR of 90\% [83]. This indicates, despite substantial heterogeneity, that more than half of the individuals who contract EVD are more likely to die. Although this CFR appears to be high, it is lower than the exaggerated figure of 90\%. This high CFR tends to cause fear and panic in the general public and hence interferes with response mechanisms [84]. The CFR in our study is similar to that reported by Lefebvre et al. [4], who reported a CFR of $65 \%$ in a study done using WHO database on EVD outbreaks. Although there have been cases of EVD and MVD with $100 \%$ CFR [8, 7], these were isolated single cases that should not be generalized by scientific community to consider Ebola and Marburg viruses as highly virulent diseases with CFR of up to 90\%. There have been reports with a higher CFR than our maximum of $76 \%[28,35,37,41]$, but these either happened long time ago [28] where there was little knowledge about the disease or happened in very remote places where health care delivery systems are not robust.

The high CFR of EVD in Republic of Congo (89\%) compared to Uganda (43\%) may be due to partly, differences in health care system and response mechanisms to outbreaks, but also the severity of the species of Ebola virus involved. For example, Uganda has developed a robust surveillance system for detecting these viral haemorrhagic fevers and epidemic response is started within hours of a positive diagnosis at a CDC supported laboratory in the country [85]. The well-established disease surveillance system and organised health care 


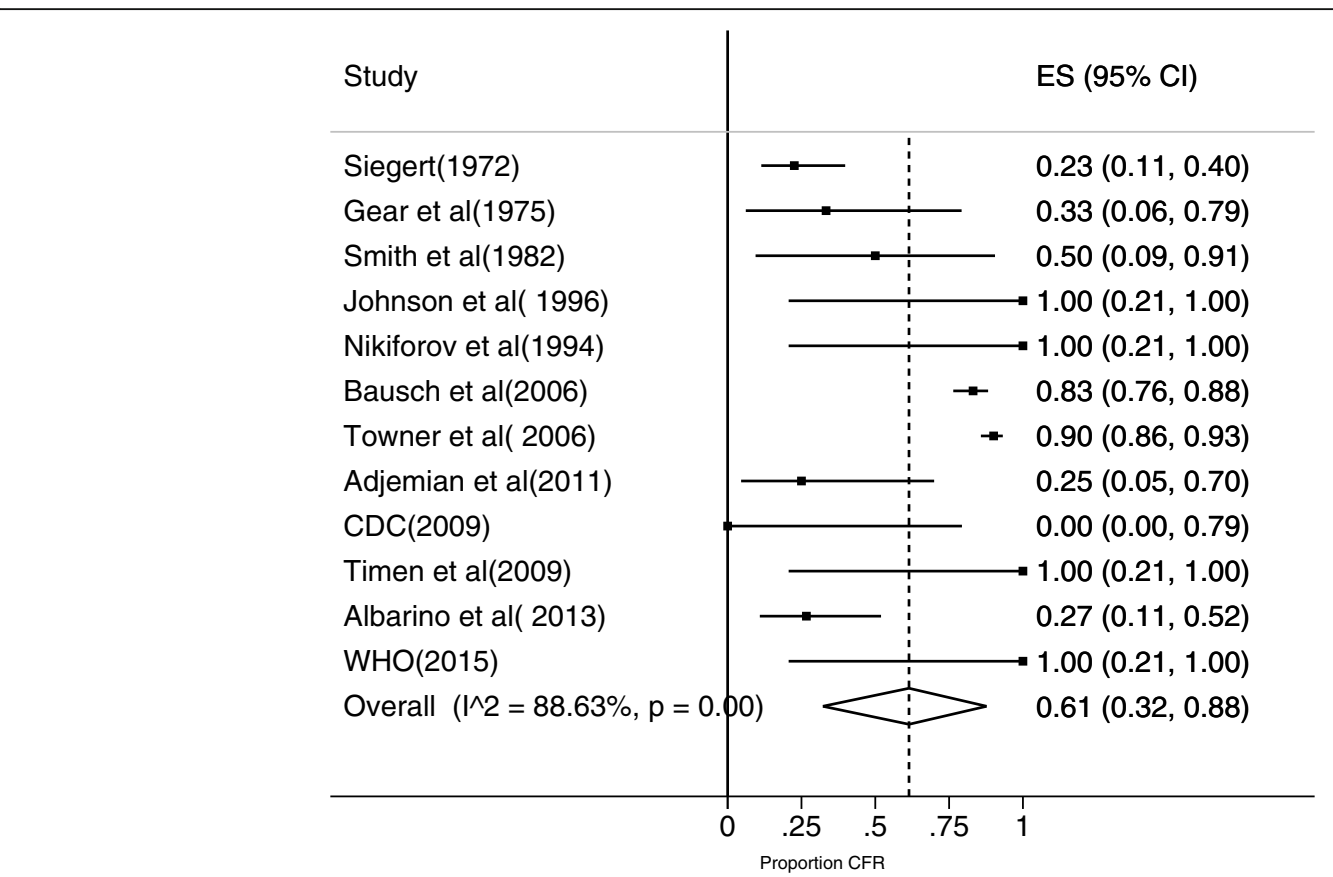

Fig. 5 Forest plot for a meta-analysis of CFR of Marburg virus disease estimated using a random effects model $\left(I^{2}=\right.$ Higgins statistic, ES $=$ Effect size, $\mathrm{Cl}=$ Confidence Interval)

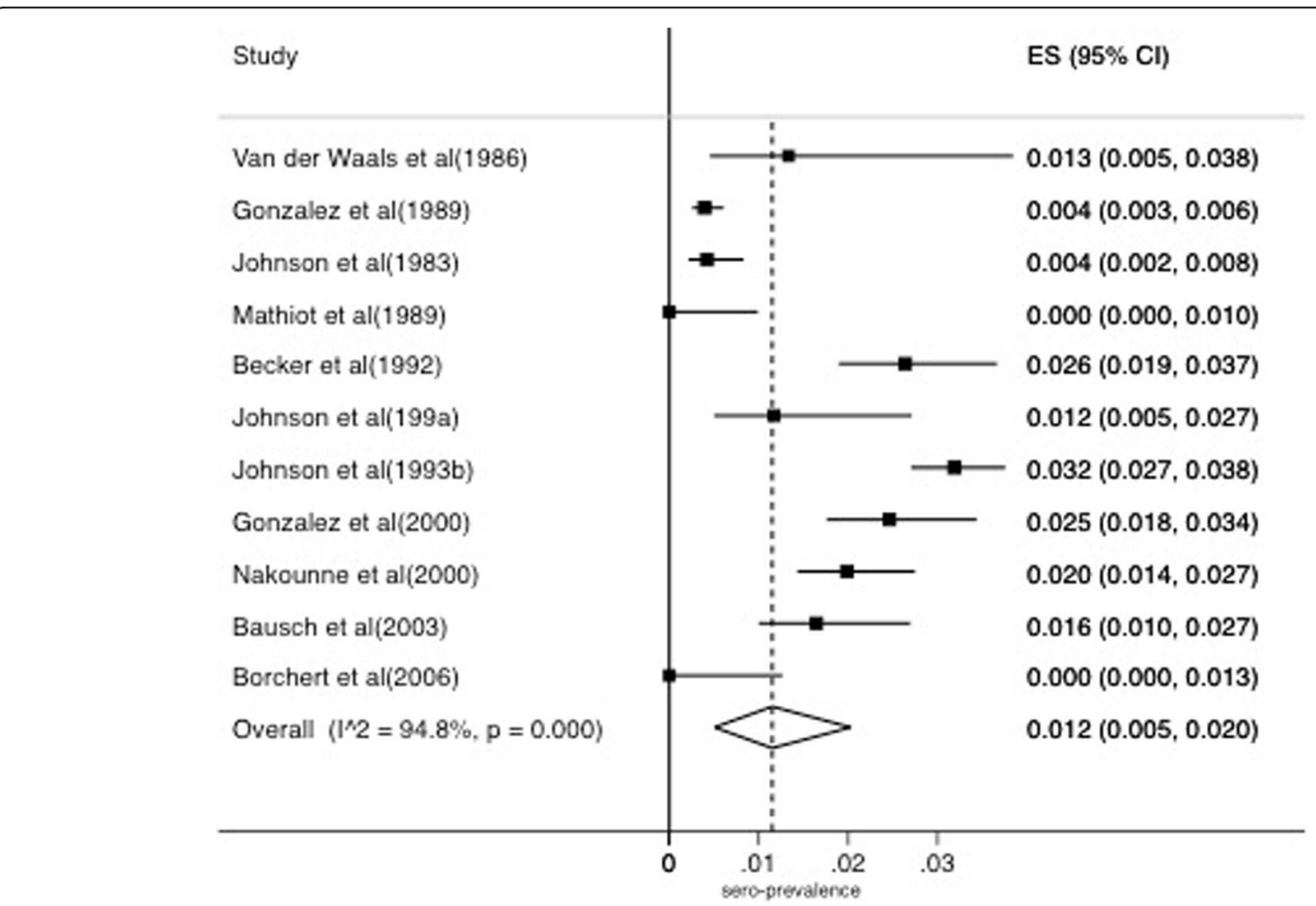

Fig. 6 Meta-analysis of seroprevalence of Marburg virus estimated using a random effects model $\left(I^{2}=\right.$ Higgins statistic, ES =Effect size, $\mathrm{Cl}=$ Confidence Interval) 


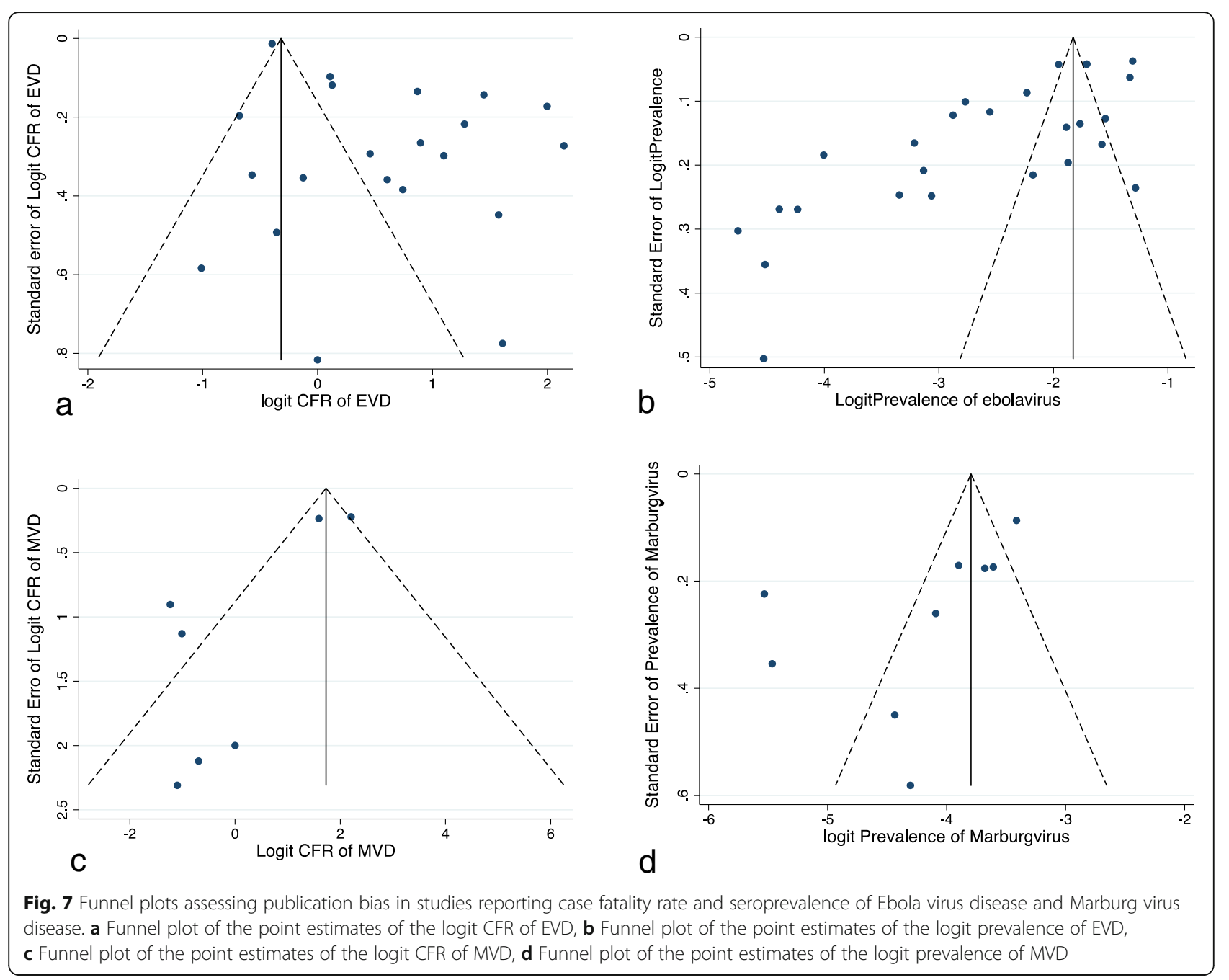

delivery in endemic areas might explain the lower CFR for EVD observed in Uganda. But it is also important to note that Uganda has been affected by the less pathogenic species of Ebola virus (Sudan ebolavirus and Bundibugyo ebolavirus) as compared to DRC and West African countries that have experienced Zaire ebolavirus Also, it is important to look at the denominators and numerators when interpreting the CFR. In this analysis, we see that CFR of EVD in a large outbreak in West Africa that affected multiple countries is at CFR of $40 \%$ using WHO data, but this alone would be misleading if the real numbers of deaths and cases were not looked at. As of $30^{\text {th }}$ March 2016, there were 11323 deaths and 28646 cases due to EVD from all countries affected by that outbreak.

Another significant finding of our study was the variation in the severity and CFR among the pathogenic species of Ebola virus. Zaire ebolavirus (CFR, 75\%) was found to be the most severe followed by Sudan ebolavirus (CFR, 53\%), while Bundibugyo ebolavirius (CFR, $34 \%)$ was the least severe species. This finding is supported by McCormick et al., who described differences in severity and filovirus dynamics [86, 87]. The reasons for severity of Zaire ebolavirus are unclear, thus there is a need for further research to determine whether genetic differences are responsible for the variation in pathogenesis of these species. There was also heterogeneity within Zaire ebolavirus outbreaks $(\mathrm{P}<0.001)$ meaning that these outbreaks, although caused by the same species are not always similar. The heterogeneity could further be explained by differences in outbreak investigation designs or approaches, location of the outbreak and data collection methods. This is further supported by the strains that have been found within Ebola Zaire species [40]. There was less heterogeneity in outbreak reports for Bundibugyo ebolavirus and Sudan ebolavirus probably due to few outbreaks that have been caused by these species. However, the meta-regression did not show any influence on CFR of EVD by country of outbreak $(p=0.249)$. This is probably due to low power given the few number of outbreaks that we have had globally. 
With the Metaprop command for meta-analysis of marginal proportions [22], it was possible to estimate the $95 \%$ confidence intervals for MVD as $61 \%$ (32-88\%). The CI was very wide because of the few outbreaks and the number of cases involved in MVD outbreaks as compared to EVD outbreaks. Dropping studies with $100 \%$ or 0\% CFR for MVD, the CFR reduced from 61 to $53 \%$. With few outbreaks of Marburg virus in different countries, there is a high variation that would impact the estimation of CFR for MVD, but this was not significant from the meta-regression $(p=0.913)$.

We found that apparently healthy individuals in central African countries, that are endemic for viral haemorrhagic fevers, had a 5 and $1 \%$ chance of having antibodies against Ebola and Marburg viruses, respectively. This finding suggests that some individuals who get infected with filoviruses make a full recovery without severe complications and being documented by healthcare systems. Although the sero-prevalence is low, it is important that these seropositive individuals are detected early enough because of greater mortality and socio-economic implications associated with these infections. Because serological tests have been reported to have low specificity and there is a lot of cross-reactivity of filoviruses with other viral haemorrhagic fevers [88], this finding should be interpreted with caution. It is important that specific and more accurate tests are developed to accurately measure antibody response against filoviruses and progress in this direction has been made due to the recently approved rapid diagnostic test for Ebola virus by WHO [89].

The limitation of our ES estimates was the heterogeneity that was observed between studies. Efforts to identify sources of heterogeneity were made, and many unmeasured factors could have influenced CFR during outbreaks. These reports had data that were collected using different methods and hence combining them to produce one effect was likely to produce high heterogeneity. Sensitivity analysis by dropping single cases with $100 \%$ mortality did not have substantial impact on the result. Funnel plots and Beggs tests suggested that publication bias might have been present, meaning that studies with negative results about Ebola and Marburg viruses are less likely to be published hence affecting the estimate of seroprevalence and CFR for EVD and MVD.

The fact that laboratory tests for Ebola and Marburg viruses are expensive, used only in specific laboratories and that serological tests are not specific might influence the publication of studies done with these tests.

\section{Conclusions}

The CFR for Ebola and Marburg viruses is still moderately high but not as high as has been reported in the media and other publications. The CFR of EVD and MVD is higher in countries with poor disease surveillance systems. This calls for an improved surveillance system that will enhance early detection and response to these filovirus outbreaks to avoid a pandemic. The presence of seropositive individuals in apparently health populations indicate that cases go undetected by the health care system in affected countries; further calling for robust surveillance for Ebola and Marburg viruses.

\section{Abbreviations \\ CDC: Centres for disease control and prevention USA; CFR: Case fatality rate; Cl: Confidence interval; DRC: Democratic Republic of Congo; EVD: Ebola virus disease; MVD: Marburg virus disease; ROC: Republic of Congo; WHO: World Health Organization}

\section{Acknowledgements \\ We thank Doreen Busingye from Monash University Australia and Doreen Asiimwe Buhwa from Makerere Univesity Kampala for final edits and formatting of this paper.}

\section{Funding}

We are grateful for funding from Norwegian Agency for Development Cooperation through the Norwegian Program for Capacity Building in Higher Education and Research for Development project of Capacity Building in Zoonotic Diseases Management using integrated approach to Ecosystems health at the human-livestock-wildlife interface in Eastern and Southern Africa.

\section{Availability of data and materials}

The dataset supporting the findings in this meta-analysis is included in the article from Tables 1, 2, 3 and 4.

\section{Authors' contributions}

Conceived and designed the protocol: LN, ES, CK. Execution of search strategy and sifting: LN, JL, BM, MF, RK. Manuscript preparation: LN, CK, RK, $B M, M F, J L$ and ES. All authors read and approved the final manuscript.

\section{Authors' information}

$L N$ is an Epidemiologist with a background in Veterinary Medicine. He has been working as a zoonotic disease Epidemiologist especially focussing of Ebola and Marburg virus outbreaks in Uganda for the last five years. He is currently pursuing a PhD in Epidemiology of Ebola and Marburg viruses in Uganda at the Norwegian University of Life Sciences, Oslo Norway.

\section{Competing interests}

The authors declare that they have no competing interests.

\section{Consent for publication}

Not applicable.

Ethics approval and consent to participate

Not applicable.

\section{Author details}

${ }^{1}$ Norwegian University of Life Sciences, Oslo, Norway. ${ }^{2}$ Makerere University, Kampala, Uganda. ${ }^{3}$ Norwegian Medicines Agency, Oslo, Norway. ${ }^{4} \mathrm{Ulm}$ University, Ulm, Germany. ${ }^{5}$ Uganda Virus Research Institute, Entebbe, Uganda.

Received: 9 June 2016 Accepted: 17 November 2016

Published online: 25 November 2016

\section{References}

1. Ebola virus disease, Fact sheet. http://www.who.int/mediacentre/factsheets/ fs103/en/. Accessed 20 June 2016.

2. Team WHOER. Ebola virus disease in West Africa-the first 9 months of the epidemic and forward projections. N Engl J Med. 2014;371(16):1481-95.

3. Wamala JF, Lukwago L, Malimbo M, Nguku P, Yoti Z, Musenero M, Amone J, Mbabazi W, Nanyunja M, Zaramba S, et al. Ebola hemorrhagic fever 
associated with novel virus strain, Uganda, 2007-2008. Emerg Infect Dis. 2010;16(7):1087-92.

4. Lefebvre A, Fiet C, Belpois-Duchamp C, Tiv M, Astruc K, Aho Glele LS. Case fatality rates of ebola virus diseases: a meta-analysis of World Health Organization data. Med Mal Infect. 2014;44(9):412-6.

5. Van Kerkhove MD, Bento Al, Mills HL, Ferguson NM, Donnelly CA. A review of epidemiological parameters from ebola outbreaks to inform early public health decision-making. Sci Data. 2015;2:150019.

6. Formenty P, Hatz C, Le Guenno B, Stoll A, Rogenmoser P, Widmer A. Human infection due to Ebola virus, subtype Cote d'Ivoire: clinical and biologic presentation. J Infect Dis. 1999;179 Suppl 1:S48-53.

7. Shoemaker T, MacNeil A, Balinandi S, Campbell S, Wamala JF, McMullan LK, Downing R, Lutwama J, Mbidde E, Stroller U, et al. Reemerging Sudan ebola virus disease in Uganda, 2011. Emerg Infect Dis. 2012;18(9):1480-3.

8. Heymann DL, Weisfeld JS, Webb PA, Johnson KM, Cairns T, Berquist H. Ebola hemorrhagic fever: Tandala, Zaire, 1977-1978. J Infect Dis. 1980;142(3):372-6.

9. Marburg Hemorrhagic Fever Outbreak in Uganda. http://www.cdc.gov/vhf/ marburg/outbreaks/uganda/2014-oct.html. Accessed 21 June 2016.

10. Towner JS, Khristova ML, Sealy TK, Vincent MJ, Erickson BR, Bawiec DA, Hartman AL, Comer JA, Zaki SR, Stroher U, et al. Marburgvirus genomics and association with a large hemorrhagic fever outbreak in Angola. J Virol. 2006; 80(13):6497-516.

11. Bausch DG, Nichol ST, Muyembe-Tamfum JJ, Borchert M, Rollin PE, Sleurs H, Campbell P, Tshioko FK, Roth C, Colebunders R, et al. Marburg hemorrhagic fever associated with multiple genetic lineages of virus. N Engl J Med. 2006; 355(9):909-19.

12. Becquart $\mathrm{P}$, Wauquier $\mathrm{N}$, Mahlakoiv $\mathrm{T}$, Nkoghe $\mathrm{D}$, Padilla $\mathrm{C}$, Souris $\mathrm{M}, \mathrm{Ollomo}$ B, Gonzalez JP, De Lamballerie X, Kazanji M, et al. High prevalence of both humoral and cellular immunity to Zaire ebolavirus among rural populations in Gabon. PLoS One. 2010;5(2):e9126.

13. Nkoghe D, Padilla C, Becquart P, Wauquier N, Moussavou G, Akue JP, Ollomo B, Pourrut X, Souris M, Kazanji M, et al. Risk factors for Zaire ebolavirus-specific IgG in rural Gabonese populations. J Infect Dis. 2011;204 Suppl 3:S768-75.

14. Gonzalez JP, Nakoune E, Slenczka W, Vidal P, Morvan JM. Ebola and marburg virus antibody prevalence in selected populations of the Central African Republic. Microbes Infect. 2000;2(1):39-44.

15. Bausch DG, Borchert M, Grein T, Roth C, Swanepoel R, Libande ML, Talarmin A, Bertherat E, Muyembe-Tamfum JJ, Tugume B, et al. Risk factors for marburg hemorrhagic fever, Democratic Republic of the Congo. Emerg Infect Dis. 2003;9(12):1531-7.

16. Amman BR, Carroll SA, Reed ZD, Sealy TK, Balinandi S, Swanepoel R, Kemp A, Erickson BR, Comer JA, Campbell S, et al. Seasonal pulses of marburg virus circulation in juvenile Rousettus aegyptiacus bats coincide with periods of increased risk of human infection. PLoS Pathog. 2012;8(10): e1002877.

17. Amman BR, Jones ME, Sealy TK, Uebelhoer LS, Schuh AJ, Bird BH, ColemanMcCray JD, Martin BE, Nichol ST, Towner JS. Oral shedding of marburg virus in experimentally infected Egyptian fruit bats (Rousettus aegyptiacus). J Wildl Dis. 2015;51(1):113-24.

18. Amman BR, Nyakarahuka L, McElroy AK, Dodd KA, Sealy TK, Schuh AJ, Shoemaker TR, Balinandi S, Atimnedi P, Kaboyo W, et al. Marburgvirus resurgence in kitaka mine bat population after extermination attempts, Uganda. Emerg Infect Dis. 2014;20(10):1761-4.

19. Towner JS, Amman BR, Sealy TK, Carroll SA, Comer JA, Kemp A, Swanepoel $R$, Paddock CD, Balinandi S, Khristova ML, et al. Isolation of genetically diverse marburg viruses from Egyptian fruit bats. PLoS Pathog. 2009;5(7): e1000536.

20. Moher D, Liberati A, Tetzlaff J, Altman DG, Group P. Preferred reporting items for systematic reviews and meta-analyses: the PRISMA statement. Open Med. 2009;3(3):e123-30.

21. Stroup DF, Berlin JA, Morton SC, Olkin I, Williamson GD, Rennie D, Moher D, Becker BJ, Sipe TA, Thacker SB. Meta-analysis of observational studies in epidemiology: a proposal for reporting. Meta-analysis of observational studies in epidemiology (MOOSE) group. JAMA. 2000;283(15):2008-12.

22. Nyaga VN, Arbyn M, Aerts M. Metaprop: a stata command to perform metaanalysis of binomial data. Arch Public Health. 2014;72(1):39.

23. Borenstein M, Hedges LV, Higgins J, Rothstein HR. Subgroup analyses, Introduction to meta-analysis. 2009. p. 149-86.

24. Borenstein M, Hedges LV, Higgins J, Rothstein HR. Publication bias, Introduction to meta-analysis. 2009. p. 277-92.
25. Higgins J, Thompson SG. Quantifying heterogeneity in a meta-analysis. Stat Med. 2002;21(11):1539-58

26. Sterne J. Comprar Meta-Analysis In Stata: An Updated Collection From The Stata Journal| Jonathan Sterne| 9781597180498| CRC PRESS: CRC PRESS, 2009.

27. Ebola haemorrhagic fever in Sudan, 1976. Report of a WHO/International Study Team. Bull World Health Organ. 1978;56(2):247-270.

28. Burke J, Declerq R, Ghysebrechts G, Pattyn SR, Piot P, Ronsmans M, Ruppol JF, Thonon D, Van Der Groen G, Van Nieuwenhove S, et al. Ebola hemorrhagic-fever in Zaire, 1976 - report of an International-Commission. Bull World Health Organ. 1978;56(2):271-93.

29. Baron RC, McCormick JB, Zubeir OA. Ebola virus disease in southern Sudan: hospital dissemination and intrafamilial spread. Bull World Health Organ. 1983;61(6):997-1003.

30. Amblard J, Obiang P, Edzang S, Prehaud C, Bouloy M, Guenno BL. Identification of the ebola virus in Gabon in 1994. Lancet. 1997;349(9046):181-2.

31. Georges AJ, Leroy EM, Renaut AA, Benissan CT, Nabias RJ, Ngoc MT, Obiang $\mathrm{PI}$, Lepage JP, Bertherat EJ, Benoni DD, et al. Ebola hemorrhagic fever outbreaks in Gabon, 1994-1997: epidemiologic and health control issues. J Infect Dis. 1999;179 Suppl 1:S65-75.

32. Khan AS, Tshioko FK, Heymann DL, Le Guenno B, Nabeth P, Kerstiens B, Fleerackers Y, Kilmarx PH, Rodier GR, Nkuku O, et al. The reemergence of Ebola hemorrhagic fever, Democratic Republic of the Congo, 1995. Commission de lutte contre les epidemies a kikwit. J Infect Dis. 1999;179 Suppl 1:S76-86.

33. Okware Sl, Omaswa FG, Zaramba S, Opio A, Lutwama JJ, Kamugisha J, Rwaguma EB, Kagwa P, Lamunu M. An outbreak of ebola in Uganda. Trop Med Int Health. 2002;7(12):1068-75

34. Milleliri JM, Tevi-Benissan C, Baize S, Leroy E, Georges-Courbot MC. [Epidemics of ebola haemorrhagic fever in Gabon (1994-2002). epidemiologic aspects and considerations on control measures]. Bull Soc Pathol Exot. 2004:97(3):199-205.

35. Boumandouki P, Formenty $P$, Epelboin A, Campbell P, Atsangandoko C, Allarangar Y, Leroy EM, Kone ML, Molamou A, Dinga-Longa O, et al. [Clinical management of patients and deceased during the ebola outbreak from October to December 2003 in Republic of Congo]. Bull Soc Pathol Exot. 2005;98(3):218-23.

36. Nkoghe D, Nnegue S, Mve MT, Formenty P, Thompson G, Iba Ba J, Okome Nkoumou M, Leroy E. [lsolated case of haemorrhagic fever observed in Gabon during the 2002 outbreak of ebola but distant from epidemic zones]. Med Trop (Mars). 2005;65(4):349-54.

37. Rouquet P, Froment JM, Bermejo M, Kilbourn A, Karesh W, Reed P, Kumulungui B, Yaba P, Delicat A, Rollin PE, et al. Wild animal mortality monitoring and human ebola outbreaks, Gabon and Republic of Congo, 2001-2003. Emerg Infect Dis. 2005;11(2):283-90

38. Onyango CO, Opoka ML, Ksiazek TG, Formenty P, Ahmed A, Tukei PM, Sang RC, Ofula VO, Konongoi SL, Coldren RL, et al. Laboratory diagnosis of ebola hemorrhagic fever during an outbreak in Yambio, Sudan, 2004. J Infect Dis. 2007:196 Suppl 2:S193-8

39. Leroy EM, Epelboin A, Mondonge V, Pourrut X, Gonzalez JP, MuyembeTamfum JJ, Formenty P. Human ebola outbreak resulting from direct exposure to fruit bats in Luebo, Democratic Republic of Congo, 2007. Vector Borne Zoonotic Dis. 2009:9(6):723-8.

40. Grard G, Biek R, Tamfum JJ, Fair J, Wolfe N, Formenty P, Paweska J, Leroy E. Emergence of divergent Zaire ebola virus strains in Democratic Republic of the Congo in 2007 and 2008. J Infect Dis. 2011;204 Suppl 3:S776-84.

41. Nkoghe D, Kone ML, Yada A, Leroy E. A limited outbreak of ebola haemorrhagic fever in Etoumbi, Republic of Congo, 2005. Trans R Soc Trop Med Hyg. 2011;105(8):466-72.

42 Albarino CG, Shoemaker T, Khristova ML, Wamala JF, Muyembe JJ, Balinandi S, Tumusiime A, Campbell S, Cannon D, Gibbons A, et al. Genomic analysis of filoviruses associated with four viral hemorrhagic fever outbreaks in Uganda and the Democratic Republic of the Congo in 2012. Virology. 2013; 442(2):97-100

43 Maganga GD, Kapetshi J, Berthet N, Kebela llunga B, Kabange F, Mbala Kingebeni P, Mondonge V, Muyembe JJ, Bertherat E, Briand S, et al. Ebola virus disease in the Democratic Republic of Congo. N Engl J Med. 2014; 371(22):2083-91.

44 Siegert R. Marburg virus. In: Canine Distemper Virus: Springer. 1972:97-153.

45 Feldmann H, Slenczka W, Klenk H-D. Emerging and reemerging of filoviruses. In: Imported Virus Infections. edn.: Springer; 1996:77-100. 
46 Gear JS, Cassel GA, Gear AJ, Trappler B, Clausen L, Meyers AM, Kew MC, Bothwell TH, Sher R, Miller GB, et al. Outbreake of marburg virus disease in Johannesburg. Br Med J. 1975;4(5995):489-93.

47 Smith DH, Johnson BK, Isaacson M, Swanapoel R, Johnson KM, Killey M, Bagshawe A, Siongok T, Keruga WK. Marburg-virus disease in Kenya. Lancet. 1982;1(8276):816-20.

48 Nikiforov V, Turovskii I, Kalinin P, Akinfeeva L, Katkova L, Barmin V, Riabchikova E, Popkova N, Shestopalov A, Nazarov V: [A case of a laboratory infection with Marburg fever]. Zhurnal mikrobiologii, epidemiologii, i immunobiologii. 1993;(3):104-106.

49 Johnson ED, Johnson BK, Silverstein D, Tukei P, Geisbert TW, Sanchez AN, Jahrling PB. Characterization of a new marburg virus isolated from a 1987 fatal case in Kenya. Arch Virol Suppl. 1996;11:101-14.

50 Centers for Disease C, Prevention. Imported case of marburg hemorrhagic fever - Colorado, 2008. Morb Mortal Wkly Rep. 2009:58(49):1377-81.

51 Adjemian J, Farnon EC, Tschioko F, Wamala JF, Byaruhanga E, Bwire GS, Kansiime E, Kagirita A, Ahimbisibwe S, Katunguka F, et al. Outbreak of marburg hemorrhagic fever among miners in Kamwenge and Ibanda Districts, Uganda, 2007. J Infect Dis. 2011;204 Suppl 3:S796-9.

52 Van der Groen G, Pattyn SR. Measurement of antibodies to ebola virus in human sera from N. W.-Zaire. Ann Soc Belg Med Trop. 1979;59(1):87-92.

53 Saluzzo JF, Gonzalez JP, Herve JP, Georges AJ, Johnson KM. [Preliminary note on the presence of antibodies to ebola virus in the human population in the eastern part of the Central African Republic]. Bull Soc Pathol Exot Filiales. 1980;73(3):238-41.

54 Saluzzo JF, Gonzalez JP, Mccormick J, Herve JP, Georges AJ, Degallier N, Johnson KM. Epidemiology of hemorrhagic fevers (Lassa, Ebola and Marburg) in human, rodent and animal populations in the Republic-ofCentral-Africa. Ann Inst Pasteur Mic. 1982;A133(3):493.

55 Bouree P, Bergmann JF. Ebola virus infection in man: a serological and epidemiological survey in the Cameroons. AmJrop Med Hyg. 1983;32(6):1465-6.

56 Johnson BK, Ocheng D, Gichogo A, Okiro M, Libondo D, Tukei PM, Ho M, Mugambi M, Timms GL, French M. Antibodies against haemorrhagic fever viruses in Kenya populations. Trans R Soc Trop Med Hyg. 1983;77(5):731-3.

57 Van der Waals FW, Pomeroy KL, Goudsmit J, Asher DM, Gajdusek DC. Hemorrhagic fever virus infections in an isolated rainforest area of central Liberia. Limitations of the indirect immunofluorescence slide test for antibody screening in Africa. Trop Geogr Med. 1986;38(3):209-14.

58 Meunier DM, Johnson ED, Gonzalez JP, Georges-Courbot MC, Madelon MC, Georges AJ. [Current serologic data on viral hemorrhagic fevers in the Central African Republic]. Bull Soc Pathol Exot Filiales. 1987;80(1):51-61.

59 Paix MA, Poveda JD, Malvy D, Bailly C, Merlin M, Fleury HJ. [Serological study of the virus responsible for hemorrhagic fever in an urban population of Cameroon]. Bull Soc Pathol Exot Filiales. 1988;81(4):679-82.

60 Tomori O, Fabiyi A, Sorungbe A, Smith A, McCormick JB. Viral hemorrhagic fever antibodies in Nigerian populations. Am J Trop Med Hyg. 1988;38(2):407-10.

61 Mathiot CC, Fontenille D, Georges AJ, Coulanges P. Antibodies to haemorrhagic fever viruses in Madagascar populations. Trans R Soc Trop Med Hyg. 1989;83(3):407-9.

62 Becker S, Feldmann H, Will C, Slenczka W. Evidence for occurrence of filovirus antibodies in humans and imported monkeys: do subclinical filovirus infections occur worldwide? Med Microbiol Immunol. 1992;181(1):43-55.

63 Johnson ED, Gonzalez JP, Georges A. Filovirus activity among selected ethnic groups inhabiting the tropical forest of equatorial Africa. Trans R Soc Trop Med Hyg. 1993;87(5):536-8.

64 Johnson ED, Gonzalez JP, Georges A. Haemorrhagic fever virus activity in equatorial Africa: distribution and prevalence of filovirus reactive antibody in the Central African Republic. Trans R Soc Trop Med Hyg. 1993;87(5):530-5.

65 Bertherat E, Renaut A, Nabias R, Dubreuil G, Georges-Courbot MC. Leptospirosis and Ebola virus infection in five gold-panning villages in northeastern Gabon. AmJTrop Med Hyg. 1999;60(4):610-5.

66 Busico KM, Marshall KL, Ksiazek TG, Roels TH, Fleerackers Y, Feldmann H, Khan AS, Peters CJ. Prevalence of $\lg G$ antibodies to ebola virus in individuals during an ebola outbreak, Democratic Republic of the Congo, 1995. J Infect Dis. 1999;179 Suppl 1:S102-7.

67 Nakounne E, Selekon B, Morvan J. [Microbiological surveillance: viral hemorrhagic fever in Central African Republic: current serological data in man]. Bull Soc Pathol Exot. 2000;93(5):340-7.

68 Allela L, Bourry O, Pouillot R, Delicat A, Yaba P, Kumulungui B, Rouquet $P$, Gonzalez JP, Leroy EM. Ebola virus antibody prevalence in dogs and human risk. Emerg Infect Dis. 2005;11(3):385-90.
69 Heffernan RT, Pambo B, Hatchett RJ, Leman PA, Swanepoel R, Ryder RW. Low seroprevalence of lgG antibodies to ebola virus in an epidemic zone: OgooueIvindo region, Northeastern Gabon, 1997. J Infect Dis. 2005;191(6):964-8.

70 Lahm SA, Kombila M, Swanepoel R, Barnes RF. Morbidity and mortality of wild animals in relation to outbreaks of ebola haemorrhagic fever in Gabon, 1994-2003. Trans R Soc Trop Med Hyg. 2007;101(1):64-78.

71 Johnson BK, Ocheng D, Gitau LG, Gichogo A, Tukei PM, Ngindu A, Langatt A, Smith DH, Johnson KM, Kiley MP, et al. Viral haemorrhagic fever surveillance in Kenya, 1980-1981. Trop Geogr Med. 1983;35(1):43-7.

72 Gonzalez JP, Josse R, Johnson ED, Merlin M, Georges AJ, Abandja J, Danyod M, Delaporte E, Dupont A, Ghogomu A, et al. Antibody prevalence against haemorrhagic fever viruses in randomized representative Central African populations. Res Virol. 1989;140(4):319-31.

73 Borchert M, Mulangu S, Swanepoel R, Libande ML, Tshomba A, Kulidri A, Muyembe-Tamfum JJ, Van der Stuyft P. Serosurvey on household contacts of marburg hemorrhagic fever patients. Emerg Infect Dis. 2006;12(3):433-9.

74 Rollin PE, Williams RJ, Bressler DS, Pearson S, Cottingham M, Pucak G, Sanchez A, Trappier SG, Peters RL, Greer PW, et al. Ebola (subtype Reston) virus among quarantined nonhuman primates recently imported from the Philippines to the United States. J Infect Dis. 1999;179 Suppl 1:S108-14.

75 Miranda ME, Miranda NL. Reston ebolavirus in humans and animals in the Philippines: a review. J Infect Dis. 2011;204 Suppl 3:S757-60.

76 Maganga GD, Kapetshi J, Berthet N, llunga BK, Kabange F, Kingebeni PM, Mondonge V, Muyembe JJT, Bertherat E, Briand S, et al. Ebola virus disease in the Democratic Republic of Congo. New Engl J Med. 2014;371(22):2083-91.

77 Okware SI, Omaswa FG, Zaramba S, Opio A, Lutwama JJ, Kamugisha J, Rwaguma EB, Kagwa P, Lamunu M. An outbreak of ebola in Uganda. Tropical Med Int Health. 2002;7(12):1068-75.

78 Nkoghe D, Formenty P, Leroy EM, Nnegue S, Edou SY, Ba Jl, Allarangar Y, Cabore J, Bachy C, Andraghetti R, et al. [Multiple ebola virus haemorrhagic fever outbreaks in Gabon, from October 2001 to April 2002]. Bull Soc Pathol Exot. 2005;98(3):224-9.

79 Ebola; Current situation. http://apps.who.int/ebola/. Accessed 20 June 2016.

80 Helleringer S, Grepin KA, Noymer A. Ebola virus disease in West Africa-the first 9 months. N Engl J Med. 2015;372(2):188-9.

81 Incident Management System Ebola Epidemiology Team CDC, Guinea Interministerial Committee for Response Against the Ebola V, World Health $\mathrm{O}$, Team CDCGR, Liberia Ministry of $\mathrm{H}$, Social W, Team CDCLR, Sierra Leone Ministry of $\mathrm{H}$, Sanitation, Team CDCSLR, et al. Update: ebola virus disease epidemic - West Africa, February 2015. Morb Mortal Wkly Rep. 2015;64(7): 186-7.

82 Gostin LO, Friedman EA. A retrospective and prospective analysis of the west African Ebola virus disease epidemic: robust national health systems at the foundation and an empowered WHO at the apex. The Lancet. 2015; 385(9980):1902-1909.

83 Allam MF. Ebola hemorrhagic fever: case fatality rate 90\%? 2014.

84 Kinsman J. "A time of fear": local, national, and international responses to a large ebola outbreak in Uganda. Globalization Health. 2012;8(1):1.

85 Borchert JN, Tappero JW, Downing R, Shoemaker T, Behumbiize P, Aceng J, Makumbi I, Dahlke M, Jarrar B, Lozano B, et al. Rapidly building global health security capacity-Uganda demonstration project, 2013. Morb Mortal Wkly Rep. 2014;63(4):73-6.

86 McCormick JB, Bauer SP, Elliott LH, Webb PA, Johnson KM. Biologic differences between strains of ebola virus from Zaire and Sudan. I Infect Dis. 1983;147(2):264-7.

87 Chowell G, Nishiura H. Transmission dynamics and control of ebola virus disease (EVD): a review. BMC Med. 2014;12(1):196.

88 Macneil A, Reed Z, Rollin PE. Serologic cross-reactivity of human IgM and $\lg$ antibodies to five species of ebola virus. PLoS Negl Trop Dis. 2011;5(6):e1175.

89 First Antigen Rapid Test for Ebola through Emergency Assessment and Eligible for Procurement. http:/www.who.int/medicines/ebola-treatment/ 1st_antigen_RT_Ebola/en/. Accessed 22 June 2016.

902014 Ebola Outbreak in West Africa - Case Counts. http://www.cdc.gov/vhf/ ebola/outbreaks/2014-west-africa/case-counts.html. Accessed 18 June 2016.

91 Gear JS, Cassel G, Gear A, Trappler B, Clausen L, Meyers A, Kew M, Bothwell T, Sher R, Miller G. Outbreake of marburg virus disease in Johannesburg. BMJ. 1975:4(5995):489-93.

92 Smith D, Isaacson M, Johnson K, Bagshawe A, Johnson B, Swanapoel R, Killey M, Siongok T, Keruga WK. Marburg-virus disease in Kenya. Lancet. 1982;319(8276):816-20. 
93 Timen A, Koopmans MP, Vossen AC, van Doornum GJ, Gunther S, van den Berkmortel F, Verduin KM, Dittrich S, Emmerich P, Osterhaus AD, et al. Response to imported case of marburg hemorrhagic fever, the Netherland. Emerg Infect Dis. 2009;15(8):1171-5.

94 Knust B, Schafer IJ, Wamala J, Nyakarahuka L, Okot C, Shoemaker T, Dodd K, Gibbons A, Balinandi S, Tumusiime A, et al. Multidistrict outbreak of marburg virus disease-Uganda, 2012. J Infect Dis. 2015;212 Suppl 2:S119-28.

95 Marburg virus disease - Uganda. http://www.who.int/csr/don/10-october2014-marburg/en/. Accessed 15 May 2016.

96 Vandergroen G, Pattyn SR. Measurement of antibodies to ebola virus in human-sera from Nw-Zaire. Ann Soc Belg Med Tr. 1979;59(1):87-92.

97 Saluzzo JF, Gonzalez JP, Herve JP, Georges AJ, Johnson KM. Ebola virus, serological survey, Central-African-Republic. B Soc Pathol Exot. 1980;73(3): 238-41

Submit your next manuscript to BioMed Central and we will help you at every step:

- We accept pre-submission inquiries

- Our selector tool helps you to find the most relevant journal

- We provide round the clock customer support

- Convenient online submission

- Thorough peer review

- Inclusion in PubMed and all major indexing services

- Maximum visibility for your research

Submit your manuscript at www.biomedcentral.com/submit 